Int. J. Electrochem. Sci., 14 (2019) 2290 - 2304

\title{
Preparation and Application of Nickel Plating on Copper Electrode (NPCE) for Uric Acid Analysis in Human Urine Using Cyclic Voltammetry
}

\author{
Riyanto* and Imaylina Rofida \\ Department of Chemistry, Faculty of Mathematics and Natural Science, Islamic University of \\ Indonesia, Jalan Kaliurang KM 14,5 Sleman Yogyakarta Indonesia 55584 \\ *E-mail: riyanto@uii.ac.id
}

doi: $10.20964 / 2019.03 .35$

Received: 2 September 2016 / Accepted: 14 January 2019 / Published: 7 February 2019

Preparation and application of nickel plating on copper electrode (NPCE) for uric acid analysis in human urine using cyclic voltammetry has been done. NPCE electrode was formulated by using copper pure $(99.99 \%$ ), with length of $0.5 \mathrm{~cm}$ and wide of $1.0 \mathrm{~mm}$ respectively. Electroplating nickel on copper has been done using $\mathrm{NiSO}_{4}, \mathrm{NiCl}_{2}, \mathrm{H}_{3} \mathrm{BO}_{3}$, brighteners and carrier solution. Optimal conditions for electroplating nickel on copper at temperature, $\mathrm{pH}$ and time are $55^{\circ} \mathrm{C}, 4.0-4.4,15-30$ minutes, respectively. Nickel plating on copper connected with silver wire using silver conductive paint. Cyclic voltammetry measurement using three electrode system are platinum wire as counter electrode, SCE was used for reference electrode, and gold wire micro electrode as working electrode. During the electroanalysis process, we used nitrogen to aerify the solutions and keep it on inert atmosphere over reaction. Sodium hydroxide was used for electrolyte solution. Electroanalysis activity of NPCE electrode for uric acid analysis in human urine using cyclic voltammetry evaluated using validation method. This study presented that the precision, recovery, linearity, limit of quantitation (LOQ) and limit of detection (LOD) were $6.32 \%, 100.95 \%, 0.998,1.98 \mathrm{mg} / \mathrm{dL}$, and $0.59 \mathrm{mg} / \mathrm{dL}$, respectively. The NPCE electrode conclusively is an excellent electrode for uric acid analysis in human urine using cyclic voltammetry method.

Keywords: validation, uric acid, human urine, gold, cyclic voltammetry

\section{$\underline{\text { FULL TEXT }}$}

(C) 2019 The Authors. Published by ESG (www.electrochemsci.org). This article is an open access article distributed under the terms and conditions of the Creative Commons Attribution license (http://creativecommons.org/licenses/by/4.0/). 